\title{
Selective Alveolar Corticotomy to Intrude Overerupted Maxillary First Molars: Analysis of Pulp Vitality
}

\author{
Corticotomía Alveolar Selectiva para la Intrusión de los Primeros Molares Superiores \\ Extruidos: Análisis de la Vitalidad Pulpar
}

\begin{abstract}
Maria Lúcia Almeida Haueisen Souza1; Dauro Douglas Oliveira²; Euardo Murad Villoria Matheus Melo Pithon ${ }^{4} \&$ Rodrigo Villamarim Soares ${ }^{5}$
\end{abstract}

SOUZA, M. L. A. H.; OLIVEIRA, D. D.; VILLORIA, E. M.; PITHON, M. M. \& SOARES, R. V. Selective alveolar corticotomy to intrude overerupted maxillary first molars: analysis of pulp vitality. Int. J. Odontostomat., 11(2):231-236, 2017.

ABSTRACT: The excessive and prolonged orthodontic treatment might result in loss of pulp vitality. Selective alveolar corticotomy is an alternative to accelerate the orthodontic treatment in adults. This study aimed to evaluate the impact of selective alveolar corticotomy associated with orthodontic intrusion on pulp vitality of overerupted maxillary first molars. Six individuals with extruded maxillary first molars were randomly selected to undergo corticotomy as coadjuvant therapy for intrusion. Pulp vitality was evaluated with thermal (Endo-Ice and Heated gutta-percha) and electric tests before the surgical procedure and after intrusion (90 days). The intrusion of all teeth was obtained (mean $2.26 \pm 0.52 \mathrm{~mm}$ ), and all teeth responded positively to pulp vitality tests before and after intrusion. This suggests that selective alveolar corticotomy did not promote pulp damage, and can be considered an effective and safe auxiliary method to intrusion of overerupted maxillary molars.

KEY WORDS: selective alveolar corticotomy, orthodontics, dental pulp test.

\section{INTRODUCTION}

Tooth movement in adults induced by orthodontic treatment has increased significantly over the last years. However, age increase difficult orthodontic tooth movement due to a reduction in the proliferation of the periodontal ligament cells, in the synthesis of organic matrix and collagen, in alkaline phosphatase activity and in cell differentiation, which also leads to a decrease in the number of osteoblast precursor cells (Ren et al., 2002).

Selective alveolar corticotomy is an alternative to accelerate the orthodontic treatment in adults. It is a surgical procedure in which only the cortical bone is cut, drilled or mechanically altered (Bhattacharya et al., 2014). After this procedure, the bone tissue initially is in a biological state called the Regional Acceleratory Phenomenon (RAP), characterized by an increased perfusion, bone turnover and decreased bone density, followed by intense remineralization and production of young bone tissue, which will be replaced by mature and more compact bone tissue (Frost, 1983; Gantes et al., 1990).

The rapid tooth movement obtained after the selective alveolar corticotomy local physiological changes such as reduced bone density and therefore less resistance to tooth movement (Hassan et al., 2010), and increase in osteoblastic and osteoclastic

\footnotetext{
${ }^{1}$ Orthodontic Resident, Pontifical Catholic University of Minas Gerais (PUC-Minas), Belo Horizonte, Brazil.

${ }^{2}$ Program Director of Orthodontics, Associate Professor, Pontifical Catholic University of Minas Gerais (PUC-Minas), Belo Horizonte, Brazil.

${ }^{3}$ Doctoral Student, Pontifical Catholic University of Minas Gerais (PUC-Minas), Belo Horizonte, Brazil.

${ }^{4}$ Associate Professor of Orthodontics, Southwest Bahia State University, Vitoria da Conquista, Bahia, Brazil.

${ }^{5}$ Program Director of Periodontics, Associate Professor, Pontifical Catholic University of Minas Gerais (PUC-Minas), Belo Horizonte, Brazil.
} 
activity in the alveolar bone derived from RAP (Murphy et al., 2009). Selective alveolar corticotomy associated with orthodontic treatment may also be indicated for the extrusion of ankylosed teeth, nonextraction treatment of crowding, canine distalization and intrusion of overerupted maxillary molars (Oliveira et al., 2008; Wilcko et al., 2008; Akay et al., 2009; Bertossi et al., 2011; Kisnisci \& Iseri, 2011).

Although excessive and prolonged orthodontic treatment might result in loss of pulp vitality (Hamersky et al., 1980), it has been reported that there is insufficient scientific evidence to prove that adequate orthodontic forces damage the human dental pulp in terms of reducing pulpal blood flow and irreversible alterations in pulpal response (Javed et al., 2015). In addition, surgically facilitated tooth movement promotes more rapid orthodontic tooth movement and the impact of this approach on pulp vitality of these teeth is also inconclusive (Kisnisci \& Iseri; Hoogeveen et al., 2014; Kharkar et al., 2010; Hernández-Alfaro \& Guijarro-Martínez, 2012; Liou \& Huang, 1998; Sukurica et al., 2007).

Therefore, the aim of this pilot study was to evaluate the impact of selective alveolar corticotomy associated with orthodontic intrusion on pulp vitality of overerupted maxillary first molars.

\section{MATERIAL AND METHODS}

Before commencement of the study, appropriate ethics approval was obtained from the Pontificial Catholic University of Minas Gerais (PUCMinas) Human Research Ethics Committee (Ethics Approval Number: CAAE 0126.0.213.000-08). The study was conducted in full accordance with the World Medical Association Declaration of Helsinki.

Participants selection. Individuals with overerupted maxillary first molars, and who had maxillary teeth that would allow assembly of the orthodontic appliance required for intrusion of the extruded maxillary first molars were included in the study. All patients received information about the study and signed a free informed consent form according to Resolution 196/6 of the National Health Council and to the Declaration of Helsinki (2000).

The following were excluded from the sample: individuals who presented chronic or aggressive periodontitis, and problems of a systemic nature that would contra-indicate the proposed treatment (i.e., pregnant women or diabetes patients). After application of the inclusion and exclusion criteria, 6 females with an age-range of 20-35 years, with extruded maxillary first molars were selected to undergo corticotomy as coadjuvant therapy for intrusion, and a sample with 6 maxillary first molars was created. Images of a representative individual may be observed in Figure 1.

Orthodontic Procedures. Brackets (GAC, Dentsply GAC International, Bohemia, NY, USA) were bonded to all teeth, except the maxillary first molars to be intruded. On the maxillary second molars and premolars, a double tube was welded to allow insertion of the stainless steel archwire (.021" x .025"), which would promote the stabilization of these anchorage units, and allow insertion of the heat activated wire (Neo-sentalloy ${ }^{\circledR}$, Dentsply GAC International), that would promote the intrusion of the maxillary first molars. It was necessary to open the top tube of the maxillary second premolars to allow a step to be made on the steel wire in the apical direction, which would not interfere in the intrusion movement. These teeth were aligned and leveled with nickel-titanium wire and the round stainless steel wires until it was possible to stabilize them with stainless steel archwire (.021"x.025"). After this the bracket was bonded on the maxillary first molar to be intruded, and after the surgical corticotomy procedure, the heat activated was used. The participants were examined every 15 days to follow-up the orthodontic intrusion. Images of a representative individual with the orthodontic apparatus may be observed in Figure 2 .

Selective Alveolar Corticotomy. The surgical protocol used was based on a previously described procedure11. Surgery was performed under local anesthesia. A complete flap was performed on the vestibular and palatine surfaces to expose the alveolar bone in the region of the maxillary first molar.

The cortical bone was perforated, using a spherical surgical bur (Meisinger ${ }^{\circledR}$ Tungsten Carbide Bur, $2.0 \mathrm{~mm}$, Neuss, Germany), with abundant and continuous irrigation with cooled saline solution. Vertical cuts were made in the cortical bone in the mesial, distal and interproximal regions, beginning (mesial and distal) 2 to $3 \mathrm{~mm}$ apically in relation to the alveolar crest and extending (interproximal) 1 to $3 \mathrm{~mm}$ above the root apex. 


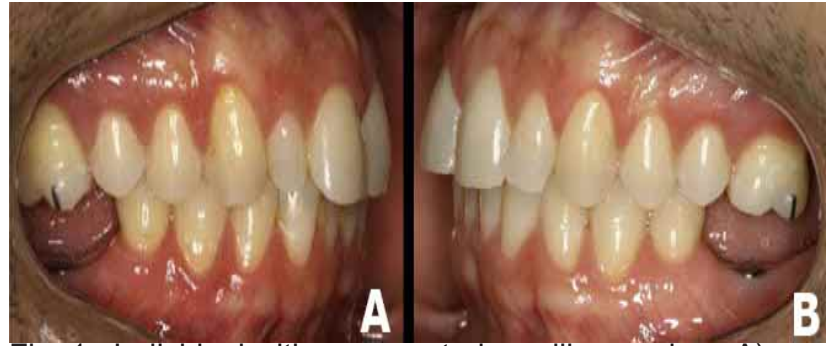

Fig. 1. Individual with overerupted maxillary molars: A) Right side view; B) Left side view.

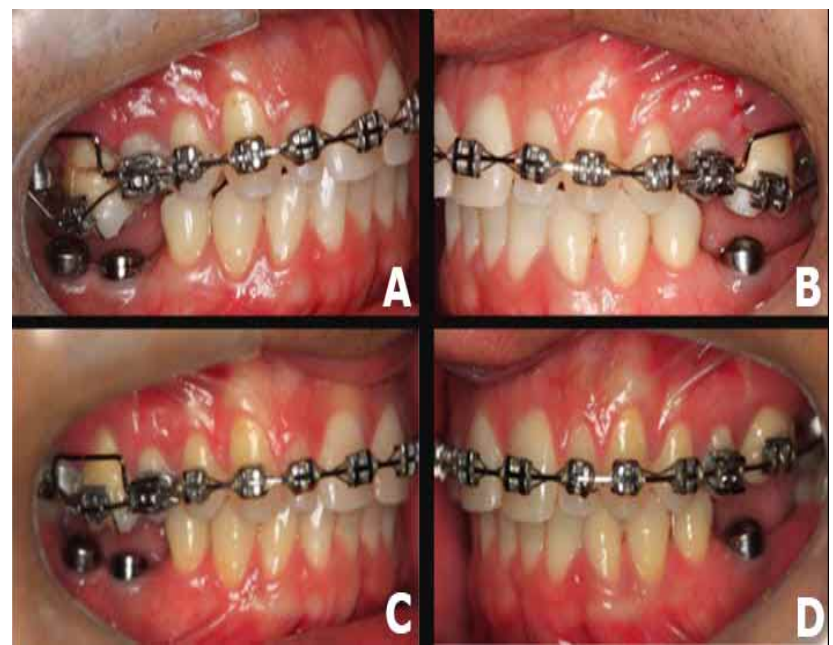

Fig. 2. Orthodontic apparatus. One week post-corticotomy: A) Right side view; B) Left side view. Two months postcoticotomy: C) Right side view; D) Left side view. alveolar corticotomy would have a deleterious effect on the neurovascular bundle of these teeth, thermal (Endo-Ice and Heated gutta-percha) and electric tests were performed before and at the end of intrusion.

\section{RESULTS}

Regarding molar intrusion, the protocol adopted promoted intrusions that ranged from $1.71 \mathrm{~mm}$ to 2.92 $\mathrm{mm}$ (mean $2.26 \pm 0.52 \mathrm{~mm}$ ) in the maxillary first molars.

In addition, the protocol did not change the response to thermal or electrical tests of the intruded maxillary molars (Table I).

Table I - Pulp vitality assessment. BC (before corticotomy); $\mathrm{Al}$ (after intrusion); + (presented similar response to the antagonist tooth that received similar stimulus); values greater than $15 \mathrm{~mA}$ are considered suitable.

\begin{tabular}{llllll}
\hline & & & & Test \\
\hline Teeth & Cold & Cold & Heat & Heat & Eletric \\
16 & + & $\mathrm{Al}$ & $\mathrm{BC}$ & $\mathrm{Al}$ & $\mathrm{BC}$ \\
16 & + & + & + & + & + \\
16 & + & + & + & + & + \\
26 & + & + & + & + & + \\
26 & + & + & + & + & + \\
26 & + & + & + & + & +
\end{tabular}

\section{DISCUSSION}

Small perforations, equivalent to the bur diameter, were made within the area circumscribed by the cuts to increase RAP stimulus, seeking to maintain the depth of the perforation within the cortical thickness. After careful irrigation, the flap was repositioned and appropriately sutured.

Evaluation of the quantity of first molar intrusion. Evaluation was made by means of superimposition of complete cephalometric tracings of the facial structures and the maxilla, originated from lateral radiographs of the face (teleradiographs) obtained before treatment and after molar intrusion.

Pulp Vitality. In order to assess whether the intrusion of upper molars associated with selective
Corticotomy was first mentioned at the end of the $19^{\text {th }}$ century (Bhattacharya et al.; Hoogeveen et al.). This surgical procedure has become an interesting alternative to increase the rate of tooth movement in adults (Andrade et al., 2014), being an alternative to reduce the treatment time and increase the stability of orthodontic treatment for complex occlusal problem (Kole, 1959).

In daily clinical routine, overerupted maxillary molars are frequently observed. This type of problem occurs in the adult population as a result of early loss of antagonist tooth (Oliveira et al.). In these situations, the intrusion of molars configures as the best treatment option. 
In this work, as described in other studies (Kravitz et al., 2007; Landes et al., 2008; Melo et al., 2008), a segmented arch made of heat activated nickeltitanium alloy wire, with the other teeth as anchoring agents, was used to intrude overerupted maxillary molars. This method was chosen because it was simple and was not influenced by other mechanisms to obtain the movement of intrusion, as would occur with the use of orthodontic mini-implants.

The pulp vitality of these teeth was evaluated by thermal and electric tests. The results related to the period of time necessary for the intrusion of maxillary first molars reveal that pulp vitality was not affected by the adopted protocol. Previous studies in which the intrusion of teeth was obtained in a period of approximately 120 days after corticotomy reported similar results (Oliveira et al.; Mostafa et al., 2009).

In contrast, other studies reported changes in pulp vitality of teeth undergoing certain types of surgically facilitated orthodontic treatment such as segmental distraction osteogenesis (Kisnisci \& Iseri; Kharkar et al.; Liou \& Huang). Regarding the orthodontic movement after selective alveolar corticotomy, some authors reported the absence of pulp damage to teeth undergoing this treatment, but did not describe the type of pulp vitality test used (Gantes et al.; Hernández-Alfaro \& Guijarro-Martínez).

The occurrence of injury, inflammation or degeneration of the pulp tissue seems to be directly associated with rapid orthodontic movement, which promotes a specific release of neurotransmitters (neuropeptides) that affects blood flow and cellular metabolism, resulting in changes in the neurovascular system of this tissue (Hamilton \& Gutmann, 1999). In a previous study that evaluated the pulp vitality of teeth undergoing moderate $(50 \mathrm{~g})$ and severe $(300 \mathrm{~g})$ intrusive orthodontic forces, electrical and thermal (heated guttapercha) tests were performed to assess pulp involvement of teeth intruded, them histological analysis was carried out on extracted teeth. The results showed that although some teeth did not respond to the electrical test, all the teeth responded positively to the thermal test. In addition, pulp stones were formed only in the severe-force group, and odontoblast disruption, vacuolization, moderate vascular congestion, and no necrosis were observed in both force. According to these authors, the pulp vitality test is crucial to monitor the state of the dental pulp, and the thermal test is considered more accurate for the assessment of pulp vitality than electrical test (Han et al., 2013).
According Chen \& Abbott (2009), patients with a history of trauma, extensive restorations and old age have reduction in the size of the pulp chamber due to dentin deposition, isolating the pulp against changes in temperature and consequently causing false-negative results. Regarding the electric test, the false-positive result can be caused by the conduction of electrical current to the periodontal tissues (Rowe \& Pitt Ford, 1990). However, according to Peters et al. (1994) rarely two tests (thermal and electric) show false results.

In this study, the assessment of pulp vitality was performed by means of thermal (heat and cold) and electric tests, revealing that the surgically facilitated orthodontic treatment associated with a more rapid tooth movement did not have a negative impact on the neurovascular bundle of these teeth, indicating that selective alveolar corticotomy, unlike subapical osteotomies (Bell \& Levy, 1972), does not cause risks related to the pulp vitality of teeth involved.

\section{CONCLUSION}

The selective alveolar corticotomy was shown to be an effective and safe auxiliary method to intrude overerupted maxillary first molars. This surgically facilitated orthodontic treatment did not promote pulp damage. However, the results of this study should be interpreted considering the small sample used.

ACKNOWLEDGEMENT. The authors declare no conflict of interest in this manuscript. This study did not receive any financial support.

SOUZA, M. L. A. H.; OLIVEIRA, D. D.; VILLORIA, E. M.; PITHON, M. M. \& SOARES, R. V. Corticotomía alveolar selectiva para la intrusión de los primeros molares superiores extruidos: Análisis de la vitalidad pulpar. Int. J. Odontostomat., 11(2):231-236, 2017.

RESUMEN: El tratamiento de ortodoncia prolongado puede provocar la pérdida de la vitalidad pulpar. La corticotomía alveolar selectiva es una alternativa para acelerar el tratamiento de ortodoncia en adultos. El objetivo del presente estudio fue evaluar el impacto de corticotomía alveolar selectiva asociada a la intrusión dental con ortodoncia en la vitalidad pulpar de los primeros molares superiores extruidos. Seis individuos con primeros molares superiores extruidos fueron seleccionados al azar para someterse a corticotomía como terapia adyuvante para la intrusión dental. La vitalidad pulpar se evaluó en ensayos térmicos (Endo-ice y gutapercha climatizada) y eléctrica 
antes del procedimiento quirúrgico y después de la intrusión (90 días). Se obtuvo la intrusión de todos los dientes (media $2,26 \pm 0,52 \mathrm{~mm}$ ) y todos los primeros molares respondieron positivamente a las pruebas de vitalidad pulpar, antes y después de la intrusión. Los resultados sugieren que la corticotomía alveolar selectiva no promueve daño pulpar y se puede considerar un método eficaz y seguro para ayudar a la intrusión de molares extruidos.

PALABRAS CLAVE: corticotomía alveolar selectiva, ortodoncia, prueba de la pulpa dental.

\section{REFERENCES}

Akay, M. C.; Aras, A.; Günbay, T.; Akyalçin, S. \& Koyuncue, B. O. Enhanced effect of combined treatment with corticotomy and skeletal anchorage in open bite correction. J. Oral Maxillofac. Surg., 67(3):563-9, 2009.

Andrade, I. Jr.; Sousa, A. B. \& da Silva, G. G. New therapeutic modalities to modulate orthodontic tooth movement. Dental Press J. Orthod., 19(6):123-33, 2014.

Bell, W. H. \& Levy, B. M. Revascularization and bone healing after maxillary corticotomies. J. Oral Surg., 30(9):640-8, 1972.

Bertossi, D.; Vercellotti, T.; Podesta, A. \& Nocini, P. F. Orthodontic microsurgery for rapid dental repositioning in dental malpositions. J. Oral Maxillofac. Surg., 69(3):747-53, 2011.

Bhattacharya, P.; Bhattacharya, H.; Anjum, A.; Bhandari, R.; Agarwal, D. K.; Gupta, A. \& Ansar, J. Assessment of corticotomy facilitated tooth movement and changes in alveolar bone thickness - A CT scan study. J. Clin. Diagn. Res., 8(10):ZC26-30, 2014.

Chen, E. \& Abbott, P. V. Dental pulp testing: a review. Int. J. Dent., 2009:365785, 2009.

Frost, H. M. The regional acceleratory phenomenon: a review. Henry Ford Hosp. Med. J., 31(1):3-9, 1983.

Gantes, B.; Rathbun, E. \& Anholm, M. Effects on the periodontium following corticotomy-facilitated orthodontics. Case reports. J. Periodontol., 61(4):234-8, 1990.

Hamersky, P. A.; Weimer, A. D. \& Taintor, J. F. The effect of orthodontic force application on the pulpal tissue respiration rate in the human premolar. Am. J. Orthod., 77(4):368-78, 1980.

Hamilton, R. S. \& Gutmann, J. L. Endodontic-orthodontic relationships: a review of integrated treatment planning challenges. Int. Endod. J., 32(5):343-60, 1999.

Han, G.; Hu, M.; Zhang, Y. \& Jiang, H. Pulp vitality and histologic changes in human dental pulp after the application of moderate and severe intrusive orthodontic forces. Am. J. Orthod. Dentofacial Orthop., 144(4):518-22, 2013.

Hassan, A. H.; Al-Fraidi, A. A. \& Al-Saeed, S. H. Corticotomy-assisted orthodontic treatment: review. Open Dent. J., 4:159-64, 2010.

Hernández-Alfaro, F. \& Guijarro-Martínez, R. Endoscopically assisted tunnel approach for minimally invasive corticotomies: a preliminary report. J. Periodontol., 83(5):574-80, 2012.

Hoogeveen, E. J.; Jansma. J. \& Ren, Y. Surgically facilitated orthodontic treatment: a systematic review. Am. J. Orthod. Dentofacial Orthop., 145 (4 Suppl.):S51-64, 2014.

Javed, F.; Al-Kheraif, A. A.; Romanos, E. B. \& Romanos, G. E. Influence of orthodontic forces on human dental pulp: a systematic review. Arch. Oral Biol., 60(2):347-56, 2015.

Kharkar, V. R.; Kotrashetti, S. M. \& Kulkarni, P. Comparative evaluation of dento-alveolar distraction and periodontal distraction assisted rapid retraction of the maxillary canine: a pilot study. Int. J. Oral Maxillofac. Surg., 39(11):1074-9, 2010.
Kisnisci, R. S. \& Iseri, H. Dentoalveolar transport osteodistraction and canine distalization. J. Oral Maxillofac. Surg., 69(3):763-70, 2011.

Kole, $\mathrm{H}$. Surgical operations on the alveolar ridge to correct occlusal abnormalities. Oral Surg. Oral Med. Oral Pathol., 12(5):515-29, 1959.

Kravitz, N. D.; Kusnoto, B.; Tsay, P. T. \& Hohlt, W. F. Intrusion of overerupted upper first molar using two orthodontic miniscrews. A case report. Angle Orthod., 77(5):915-22, 2007.

Landes, C. A.; Glasl, B.; Kopp, S.; Sader, R. \& Ludwig, B. Microanchor mediated upper molar intrusion in deep posterior bite after longterm edentulousness for prosthetic reconstruction with dental implants. Oral Maxillofac. Surg., 12(3):155-8, 2008.

Liou, E. J. \& Huang, C. S. Rapid canine retraction through distraction of the periodontal ligament. Am. J. Orthod. Dentofacial Orthop., 114(4):372-82, 1998.

Melo, A. C.; Jawonski, M. E.; Largura, L. Z.; ThomÉ, G.; de Souza, J. R. \& da Silva, M. A. Upper molar intrusion in rehabilitation patients with the aid of microscrews. Aust. Orthod. J., 24(1):50-3, 2008.

Mostafa, Y. A.; Mohamed Salah Fayed, M.; Mehanni, S.; ElBokle, N. N. \& Heider, A. M. Comparison of corticotomy-facilitated vs standard tooth-movement techniques in dogs with miniscrews as anchor units. Am. J. Orthod. Dentofacial Orthop., 136(4):570-7, 2009.

Murphy, K. G.; Wilcko, M. T.; Wilcko, W. M. \& Ferguson, D. J. Periodontal accelerated osteogenic orthodontics: a description of the surgical technique. J. Oral Maxillofac. Surg., 67(10):21606, 2009.

Oliveira, D. D.; de Oliveira, B. F.; de Araújo Brito, H. H.; de Souza, M. M. \& Medeiros, P. J. Selective alveolar corticotomy to intrude overerupted molars. Am. J. Orthod. Dentofacial Orthop., 133(6):902-8, 2008.

Peters, D. D.; Baumgartner, J. C. \& Lorton, L. Adult pulpal diagnosis. I. Adult pulpal diagnosis. I. Evaluation of the positive and negative responses to cold and electrical pulp tests. J. Endod., 20(10):50611, 1994.

Ren, Y.; Maltha, J. C.; Van't Hof, M. A.; Von Den Hoff, J. W.; KuijpersJagtman, A. M. \& Zhang, D. Cytokine levels in crevicular fluid are less responsive to orthodontic force in adults than in juveniles. J. Clin. Periodontol., 29(8):757-62, 2002.

Rowe, A. H. \& Pitt Ford, T. R. The assessment of pulpal vitality. Int. Endod. J., 23(2):77-83, 1990.

Sukurica, Y.; Karaman, A.; Gürel, H. G. \& Dolanmaz, D. Rapid canine distalization through segmental alveolar distraction osteogenesis. Angle Orthod., 77(2):226-36, 2007.

Wilcko, M. T.; Wilcko, W. M. \& Bissada, N. F. An evidence based analysis of periodontally accelerated orthodontic and osteogenic techniques: A synthesis of scientific perspectives. Semin. Orthod., 14(4):305-16, 2008.

Corresponding author:

Eduardo Murad Villoria

Pontificial Catholic University of Minas Gerais

(PUC-Minas)

Postgraduate Program in Dentistry

Av. Dom José Gaspar, 500.

Prédio 46, sala 101 - Coração Eucarístico,

Belo Horizonte - MG.

BRAZIL

E-mail: d.villoria82@yahoo.com.br

Received: 17-04-2017

Accepted: 05-06-2017 